NATALIJA GONČAROVA

904:730.032.041.5(38)

Anthropology Department, Faculty of Biology,

COBISS.SR-ID 228054284

Lomonosov Moscow State University,

Moscow, Russia

1455008@gmail.com

Original research article

Received: May $30^{\text {th }} 2016$

Accepted: June $20^{\text {th }} 2016$

ANTON BELIKOV

Department of Aesthetics,

Institute of Philosophy,

Russian Academy of Sciences

Moscow, Russia

\title{
GREEK FACES. ANTHROPOLOGICAL ANALYSIS OF ANCIENT GREEK SCULPTURE
}

\begin{abstract}
This articleis devoted to studying the prospects of using anthropological methods to identify patterns of building sculptural forms. Authors use a well-studied by art history Greek archaic \& classic sculpture as a subject of their study. The intent of the work is to reveal the mechanism of the evolution of the art image in Greek sculpture from the different time periods. The dividing of anthropological features out of those which reflect cultural patterns and trends, such as canon, is exceedingly problematic. Nevertheless the applying of anthropological methods to analyze art objects creates a new methodology and reveals tendencies in the evolution of the image.

The study allows us to mark out the characteristics of the image related to the proportions regulated by the canon from the really anthropological features such as a structure of the periorbital area and facial horizontal profile. The stability of the reproduction of these features through time and space suggest the influence on the images of the real anthropological environment. The change of the image in the VI-V cc. BC presumably reflects the change of the anthropological type which took place in the remote past.

The study of the faces of the sculptures reveals the proportional similarity of the Palmyra funerary sculpture and the Greek archaic images.
\end{abstract}

KEYWORDS: GREEK SCULPTURE, FACE PROPORTIONS, COMPOSITE PORTRAITS, EVOLUTION OF ART IMAGE.

\section{INTRODUCTION}

Ancient Greek sculpture is a well-studied phenomenon in the history of the world culture. It has been the subject of detailed study by representatives of various scholarly fields: historians and art theoreticians, esthetic philosophers and culturologists. They have developed a complete picture of processes that took place during the "Great Awakening". Generations of artists and sculptors in modern times have been brought up copying ancient images. The fact that this topic has been thoroughly explored allows investigators to use ancient sculpture for verifying certain hypotheses and testing methodology of studying artistic visualization that can be further used to explore other less investigated artistic traditions. Greek sculpture is often viewed by a researcher through their perception of a concrete object as a masterpiece, i.e. a unique phenomenon. The idea 
of this research is trying to view Greek sculpture as a statistical sampling, where each work of art is a variant of an established method of artistic expression of the human image. This approach is based on methods of anthropological science with more elaborated apparatus allowing typologization of human images. The purpose of such an interdisciplinary overview is to define patterns of evolution of the artistic image in ancient sculpture during different historical periods. Separating anthropological characteristics of the art image from those reflecting cultural patterns and trends, such as the canon, poses a particular problem for a culturologist in their research.

In this connection, interdisciplinary (anthropological) methods allow scientists to test different methodologies and consider trends in the artistic image development (taking ancient images as an example) that are difficult to discern in less explored traditions.

The present research is an attempt to use classic anthropometric methods for analysis of objects that are not, strictly speaking, the subject of anthropology. Nevertheless, in different cultural periods, researchers dealt with certain cultural objects because portraits and sculptures of the human face, on the one hand, contain anthropological information, while on the other they, to the great extent, reflect those cultural processes that would take place in different time periods. (Беликов и Гончарова 2012)

The authors have offered a hypothesis of Greek sculpture as a representation of a real-life anthropological type meaning that sculpture can bear the imprint of the "anthropological environment". This hypothesis is not original, with D. Pontikos, a Greek researcher, being among its advocates stating that anthropological peculiarities of Greek population of the antiquity have been preserved (URL:http://dienekes.blogspot.ru/), which does not contradict the paradigm of the conservative nature of the anthropological type. To prove his hypothesis, Pontikos offers composite portraits of Greek sculpture and a modern Greek person

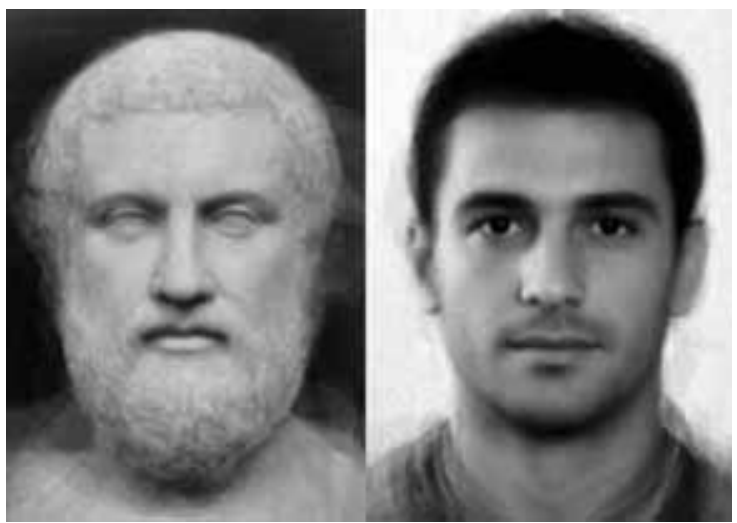

Fig. 1 Composite portraits of Greek sculpture and a modern Greek person.

(Fig.1) put together by Perret's method (Perrett, May and Yoshikawa 1994).

Following this logic, we have created several composite "portraits" of Greek sculptures having grouped them according to the accepted classification of the Ancient Art periods. To achieve this, we chose front view photographs of sculptures (early VII - late IV BC). This period is characterized by the development of the Archaic style, formation and development of the Classic style and its transformation into the Hellenistic Art. Such composite portraits have been created with the aid of Adobe Photoshop by the method of emulation suggested by F. Galton (Galton 1879, Беликов, Гончаров и Гончарова 2014). It will not be difficult to notice that these composite portraits belonging to various historical periods demonstrate obvious differences. The differences can be accounted for not only by the change in the artistic workmanship, but also its anthropological content. Examination of the artistic image evolution from the Archaic to the High Classic period shows a significant change of the art image over a period of only 250 years (Fig. 2).

Provided the anthropological type is stable, such differences may prove that at first the statement of continuity of the anthropological type is false, or secondly that sculpture is not its direct reflection. This is where the question arise of what sculpture does reflect. It is logical to suppose that sculpture, apart from its dependency on the 


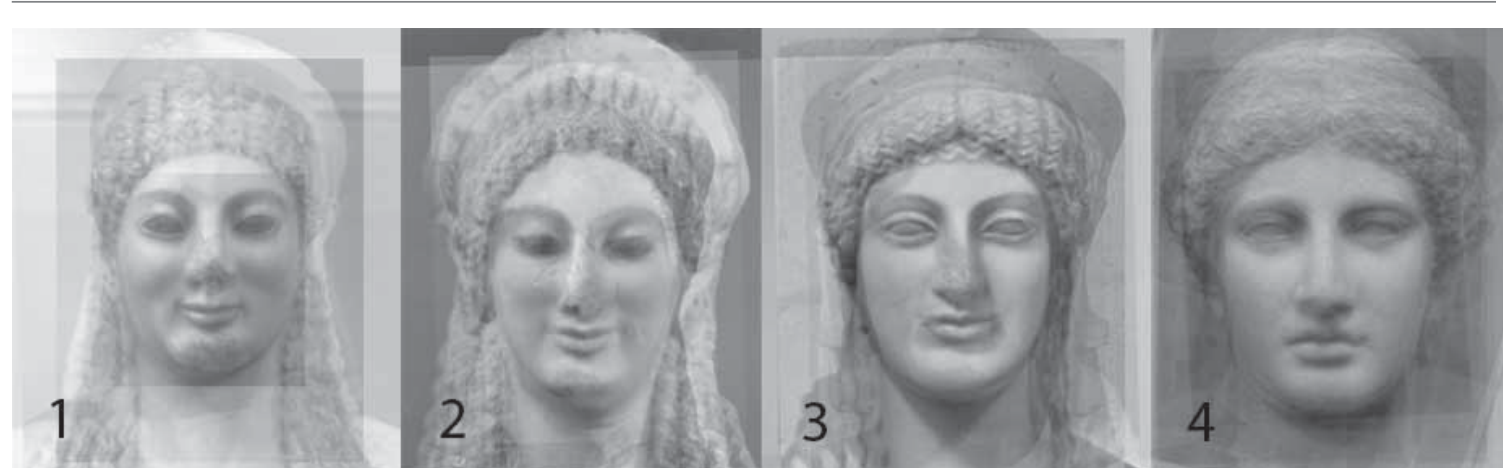

Fig. 2 Composite portraits from different periods. 1 - The High Archaic;

2 - The Mature Archaic; 3 - The Severe Style; 4 - The High Classic.

real-life anthropological environment, demonstrates some and much more deeper dependency on cultural processes that took place in the given period. Greeks founded their art on the concept of "mimesis", i.e. emulation. At that, emulation did not represent simple nature copying, typical of the Romans. In the process of creation of an image, a Greek master always followed, to a certain extent, canons - widely adopted proportional systems. Thus, in our research we may single out two extremes, between which Greek visual artistry developed. The first extreme is the closest reproduction of the visible form. This thought finally leads to the idea of the direct use of a model. The second extreme is emulation of the ideal essence of an object, unchangeable and perfect, which is expressed through the numeric or proportional canon.

Besides these two methods of emulation, we also ought to bear in mind the creation of an artistic object, which implies that the final product of the sculptor's work is influenced by the artistic consciousness and perception typical of a historic period. This specific understanding is expressed in the choice of relevant and meaningful features of a person that the master tries to convey in the sculpture. Any visual perception is inseparable from the problem of recognition, where the style and manner appear as a specific discourse of such recognition. Sculpture and its prototype are separated by the personality of the artist being influenced by the whole system of stereotypes relating to structures of cognition and perception. The development of such structures determines the characteristic features of the human image of a particular historical period.

Common examples of such structures are:

The specific process of work with a model adopted at a given place and time, as well as each individual sculptor's interpretation of his work.

The level of artistic skills and technological possibilities along with the general level of technological development in the community.

Normative systems and rules regulating the creation of an artistic object (canons), as well as the artist's understanding of such canons.

Local nuances of artistic taste and master's personal esthetic preferences.

Master's personal visual experience revealing itself in the degree and quality of its influence on the image of a specific anthropological environment.

The appearance of first local canons, independent from the Egyptian ones, signified the watershed between the Archaic and the Classical periods in Greek Art. In the Classical and Early Hellenistic periods, there were several such canons, but the most important one is the earliest and most famous Poliklet's Canon. The renowned artist is believed to have developed an instructional text based on the system of Pythagorean geometric calculations. The text was a collection of proportions of the human body in relation to the height and one to another. The master created the famous statue of Doriphorus to illustrate his calculations. It is clear that application of such systems should result in unification of images and making these 
images more general, non-concrete, idealised.

The creation of composite portraits made evident certain "ideal" images typical of each historic period (see Fig. 2). These obvious differences between the composite portrait of the Archaic and the Classical sculpture suggest that they can be described not only visually, but also with formal, statistical methods.

\section{MATERIALS AND METHODS}

Personal photographs of alabaster sculptures from the collection of the Munich Museum of Ancient sculpture replicas as well as photographs of the Archaic sculpture published by Gisela M. Richter (Richter 1942) were taken for the base. The total number of photographic images used were 177 in the front view and 60 in profile. All pictures were made according to the requirements of scientific research photography.

Damaged and obviously anatomically incorrect sculptures were excluded from the sample. As a consequence, all sculptures related to the Early Archaic period were also excluded because the level of artistic skills in that period could not provide the anatomical accuracy of statues.

Similarly, we did not include portraits of the Hellenistic and Roman periods into the sample, because we dedicated our research to the study of typical features in "ideal" images, not connected with the direct emulation of a model. New actualization of the idea of creation of "idealized" images in the Late Antiquity is closely linked with the Palmyra Art. For this reason, a series of Palmyra funeral portraits was used as a reference group, with which we decided to compare the whole set of images specific for earlier periods. This comparison was aimed at revelation of characteristic features of the image determined by canons and separation from those depending on the anthropological environment.

The material was grouped according to the conventional Art history classification:

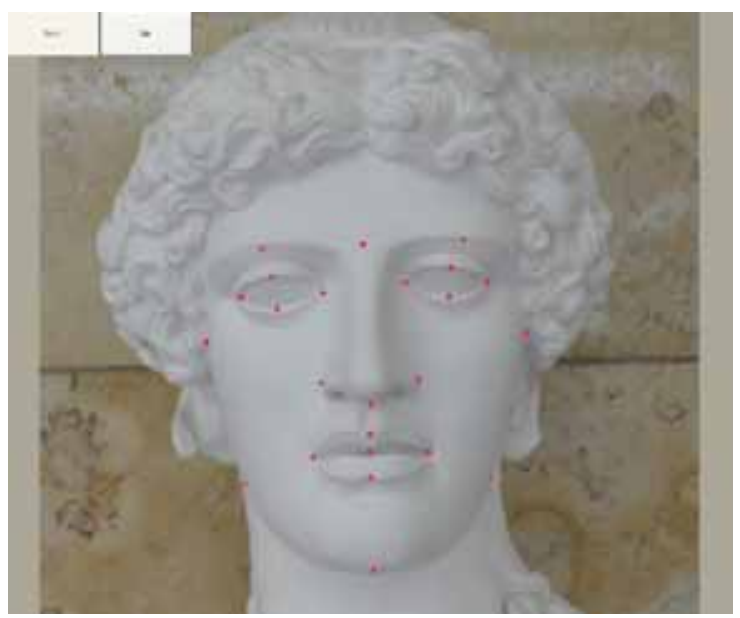

Fig. 3 Reference points for measurements.

High Archaic (570-525 BC)

Mature Archaic (525-490 BC)

Severe Style (480-430 BC)

High Classic (450-400 BC)

Late Classic (400-435 BC)

Hellenistic Art (325-30 BC)

Palmyra funeral portraits (II-III AD)

As mentioned earlier, statues of the Early Archaic period were not included in the analysis. Moreover, we combined the groups of Late Classic and Hellenistic periods in our statistical calculations, because their stylistic difference is rather vague. To sum up, 6 groups of photographs were analysed: "Archaic I" (corresponds to the style of the High Archaic period), "Archaic II" (Mature Archaic), "Severe Style", "High Classic", "Late Classic", "Hellenistic" and "Palmyra portrait".

The authors would like to thank the Vocord Company, a provider of human face recognition software, for the opportunity to use their product adapted to our purpose. To obtain measurements using Vocord software, reference points were set on each image (Fig. 3), and distance, as well as angles between them, were measured. We also determined classical measurement characteristics conventional for the statistical analysis: morphological height of face (H1), height of upper face (H2), height of lower face (height of lower jaw), relative thickness of lips, the widest part of face (cheekbones, D1), lower jaw width (D2, bigonial 

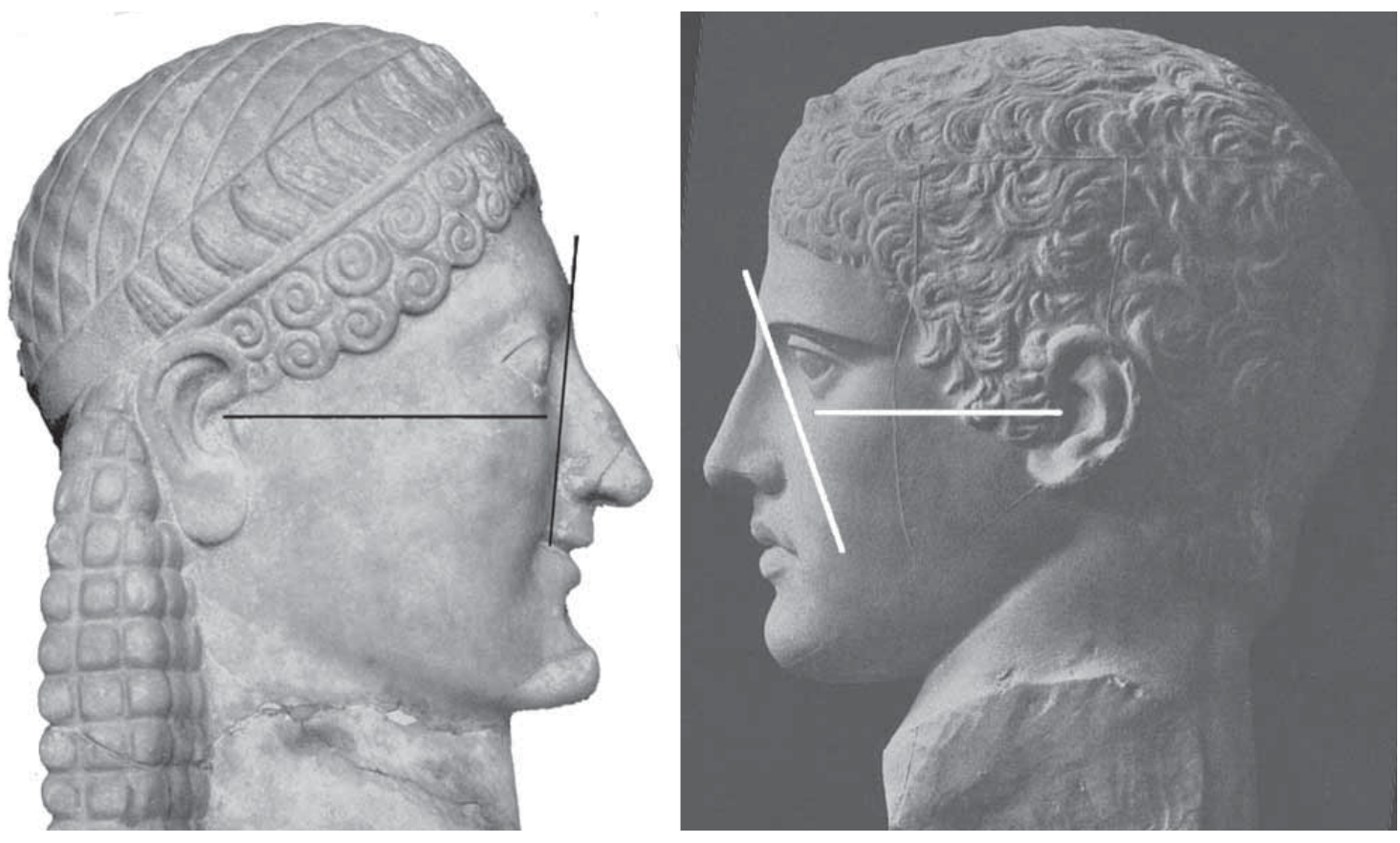

Fig. 4 Measurement of vertical profile of the orbit.

width $)^{1}$, nose width. Moreover, we calculated inclination angles of the right and left palpebral fissures. The only possible reference method was comparison of their proportions (indices), because all evaluated images were different in size. The following ratios were calculated: morphological index of face (H1:D1), index of upper face (H2:D1), as well as the relation of nose width to the cheekbone width of face and height of lips to morphological height of face. Thus, values for the relative nose width and relative thickness of lips were received. The total value of the angle between palpebral fissures was calculated based on inclination angles of the right and left palpebral fissures. This total value does not depend on the inclination of the image. Besides, two indices necessary for our research were calculated, namely, the index of face heights and the index of correlations of face widths. The first one is the ratio

1 The authors realize that the measurement of the width between the angles of the lower jaw in a picture is not identical to the measurement of this parameter on the real face, because in the front view the angles of the lower jaw are often not visible at all. However, this methodological assumption seems reasonable on the condition that only data obtained from sculpture images are subjected to the group comparison. of the upper face height to the morphological face height ( $\mathrm{H} 2: \mathrm{H} 1)$.

It is evident that large values of this index correspond to proportional reduction of the lower jaw height in the total face height and vice versa, reduction of the index of face heights signifies increase of the lower level of face. The second index is the ratio of the width between the corners of the lower jaw to the cheekbone width of face (D2:D1, bigonial width: cheekbone width). The increase of this index corresponds to accretion of the width of the lower level of face, at that, the shape of the face becomes more rectangular. The decrease of D2:D1 index means decrease of the lower width of face in comparison with the cheekbone width, at that the face becomes more triangular.

We evaluated characteristics of the profile images that are not usually a part of the standard statistical software. However, we thought it might be interesting to compare the degree of convexity of the eyeball and the inclination angle of the orbits in sculptures of different historical periods. These characteristics are described by M. M. Gerasimov and, according to his study, they explain the difference between the Caucasian and Mongoloid groups. Thus, if the eyeball protrudes beyond the 


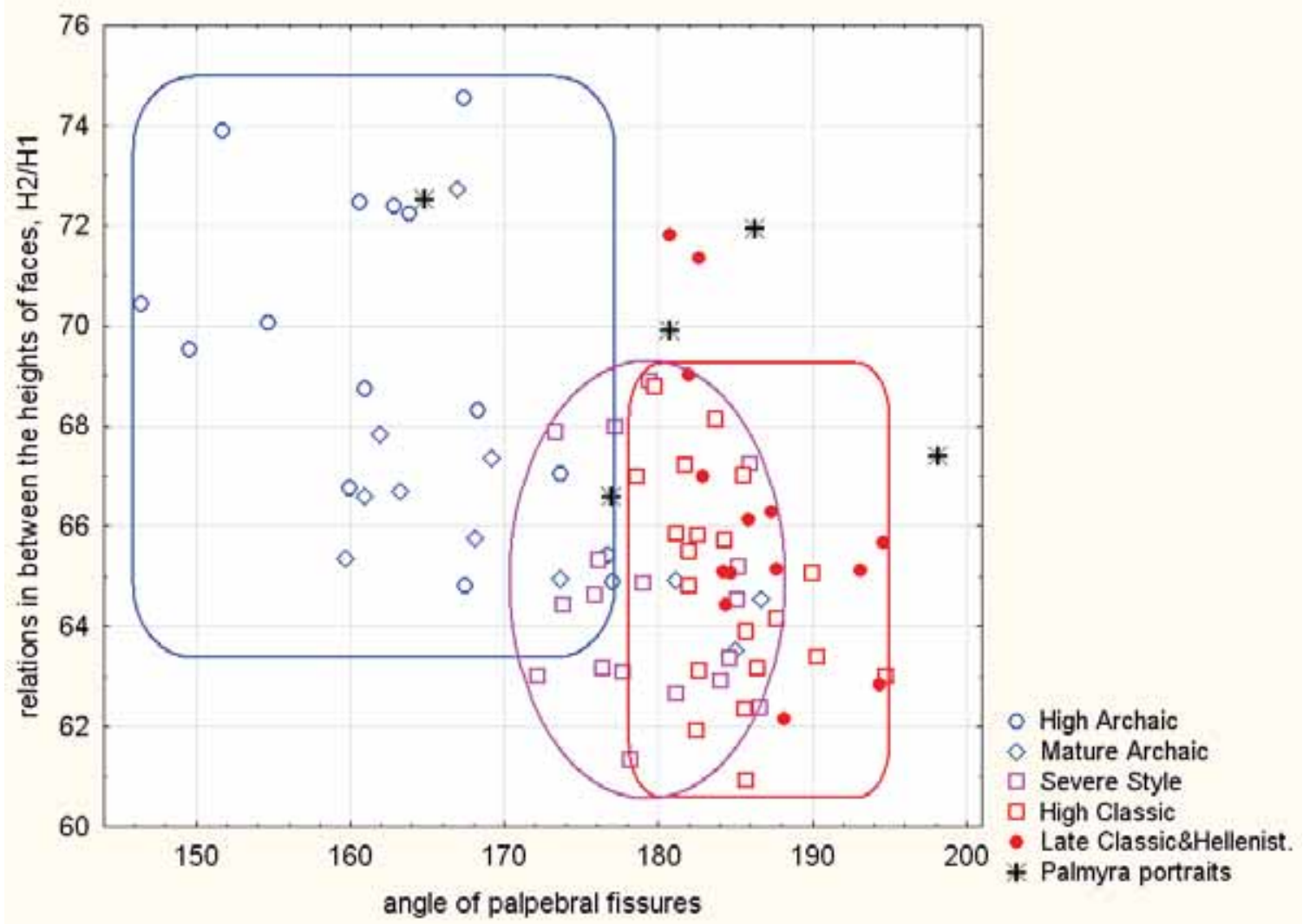

Fig. 5 The diagram of bivariate correlations. The positioning of samples in the space of two characteristics. Male sculpture, division into six periods.

frontal surface of the orbit, it evidences the open structure of the orbit, which is typical of Mongoloid groups (Fig. 4.)

Contrary to the abovementioned, a deeper placement of the eyeball corresponds to the enclosed type of orbits, which is typical of the Caucasian groups (Герасимов 1955:74.) This characteristic was evaluated on the binary scale as "present-absent". On the profile images of the face, we may notice one more characteristic feature separating race groups - the orbit profile. M.M. Gerasimov singles out two types of orbit positioning: vertical, more typical of Mongoloids, and inclining, typical of Caucasians (Герасимов 1955: 75-76) With the vertical orbit positioning, the angle between the German horizontal and the frontal surface of the orbit is close to right (and, in some cases, becomes acute), while with the inclining orbit positioning, the angle is blunt (Fig.
4). These observations were confirmed by the latest research. So, V.Bakholdina established reliable differences between Caucasians and Mongoloids on these characteristics. She stated that greater openness of Mongoloid orbits manifests itself in the lesser value of external hollows and their vertical profile is less than that of Caucasians (Bakholdina, 2002: 23-24). The angle of orbit inclination, corresponding to the angle between the German horizontal line and the line connecting the upper edge of the orbit and the most protruding point of the cheekbone, was measured in degrees in Adobe Photoshop.

The received indices and values became main characteristics of the examined faces and were later used in the statistical analysis of the material. The analysis of sculpture was conducted according to the same principles as in conventional anthropology, i.e. male sculptures were assessed separately 


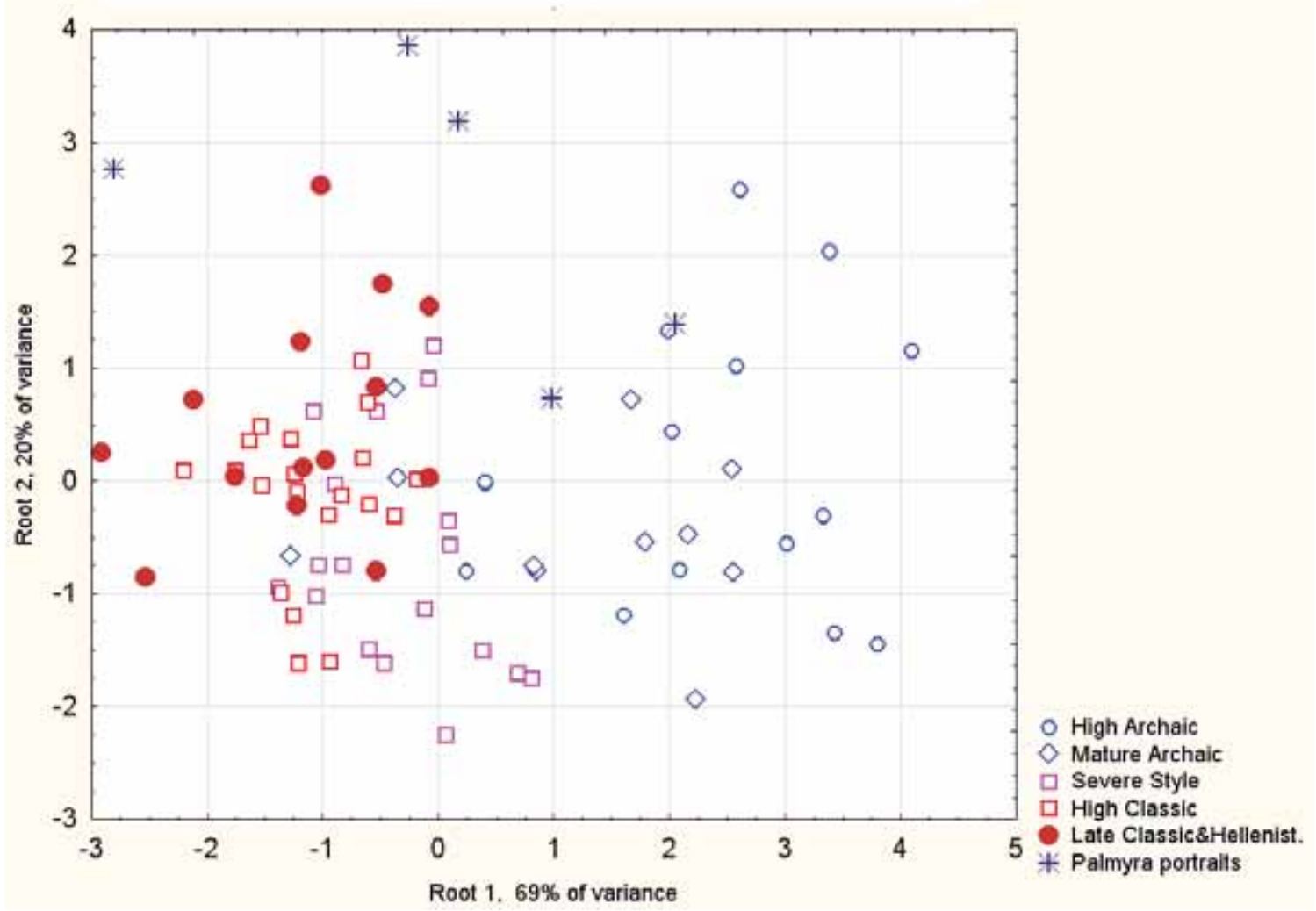

Fig. 6 Positioning of sculpture samples in the space of canonical variables. Male sculpture, division into six periods.

\begin{tabular}{|c|c|c|c|}
\hline & period of Art style & $\begin{array}{c}\text { vertical profile } \\
\text { of the orbit }\end{array}$ & $\begin{array}{c}\text { convexity of } \\
\text { the eyeball }\end{array}$ \\
\hline period of Art style & 1 & 0.68 & -0.59 \\
\hline $\begin{array}{c}\text { vertical profile } \\
\text { of the orbit }\end{array}$ & 0.68 & 1 & -0.61 \\
\hline convexity of an eyeball & -0.59 & -0.61 & 1 \\
\hline
\end{tabular}

Table 1. Correlations between the period of art, the vertical profile of the orbit and convexity of the eyeball

from female ones. We applied standard statistical procedures to determine the differences between faces of various historical periods: Student's t-test and Hoteling's T-square distribution test, analysis of variance and discriminant analysis.

\section{RESULTS AND DISCUSSION}

The analysis of variance was used for selection of characteristics demonstrating reliable differences between the groups. Among such character- istics are: the angle between palpebral fissures, the ratio between heights of face, the ratio between widths of face, and thickness of lips. The diagram reflecting placement of individual samples in the space of two characteristics was plotted to illustrate the most expressed differences on these parameters: the angle of inclination of palpebral fissures and correlation of heights of face (Fig. 5.) The diagram demonstrates distinct differences in these characteristics between the Archaic as well as High and Late Classic groups. At that, there is no transgression between, for instance, the High 


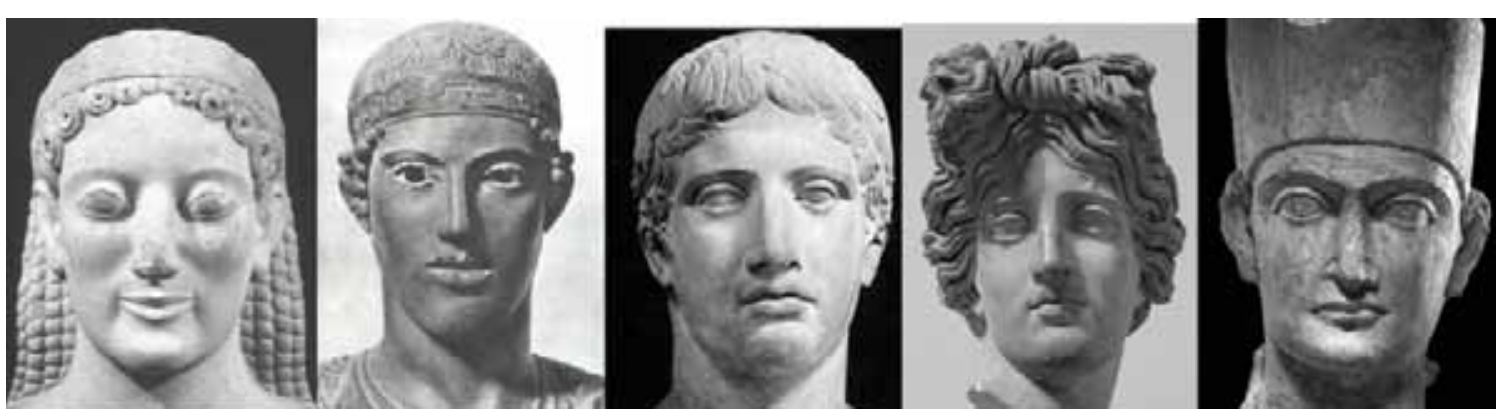

Fig. 7 From left to right: Archaic, Severe Style, High Classic, Hellenistic, Palmyra sculpture.

Archaic group (Archaic I) and the High Classic at all, while only three samples out of "Archaic II" fall into the zone of compact placement of classic sculptures. The "Severe Style" group, as was expected, takes an intermediate position between two such isolated conglomerates. As for Palmyra funeral portraits, the eye placement tends to the Greek Classic period, although the correlation between the heights of face drifts towards the Archaic sculpture. It is worth noting that the patterns discovered as a result of such a simple analysis of only two characteristics were later confirmed by multivariate methods as well.

The application of the discriminate analysis ${ }^{2}$ for male sculptures using six stylistic groups conventionally selected in the history of art resulted in data plotted in Fig. 6. According to the first canonical variable (Root 1 ), the groups were separated by a complex of characteristics including the eye inclination angle, lip thickness and index of face widths. A lesser value of angle of inclination of palpebral fissures correlated with a lesser value of lip thickness and a greater index of face widths. It may be illustrated as follows: the outer corner of eye is higher than the inner, thin lips, with the shape of face being more rectangular. Along the $\mathrm{x}$-axis, the Archaic sculpture is considerably isolated from the rest with only a few samples falling in to the space of the Classic sculpture.

2 Discriminant function analysis is used to determine which variables discriminate between two or more naturally occurring groups. A biologist could record different characteristics of similar types (groups) of objects, and then perform a discriminant function analysis to determine the set of characteristics that allows for the best discrimination between the types.
The second canonical variable (Root 2) divides the groups according to the complex of characteristics including the ratio of heights of face $(\mathrm{H} 2: \mathrm{H} 1)$, the angle of orbit inclination and lip thickness. It is evident that the dividing characteristics are repeated, while the leading role in the division of samples on the second parameter is played by the correlation of heights of face, which essentially defines the correlation of the levels of face. Relatively small values of the angle between palpebral fissures (the direct placement of orbits of slightly inclined towards the centre) are typical of samples with the heavy lower jaw and relatively thick lips. The maximum differences on this vector (y-axis) are found in certain samples of the Severe style (the lower part of the coordinate space) and the Palmyra funeral portrait (the upper part of the space). The remaining groups are more or less evenly distributed between these extremes. Summing up the differences on both axes, it is possible to say that on the right side of the space, there are samples with the rectangular face, thin lips and slanted eyes (the outer corner higher than the inner), at that, in the lower part of the space, the lower jaw is heavier and lips are thicker. On the left side of the space, the correlation of the characteristics is reverse: faces are more triangular with relatively thick lips, with the outer corner of the eye being lower than the inner one. At the same time, as in case with the right side of the space, samples with the high lower level of face are placed in the lower part of the plot, which in fact corresponds to the heavy lower jaw. Fig. 7 demonstrates the most more typical images of each period. 


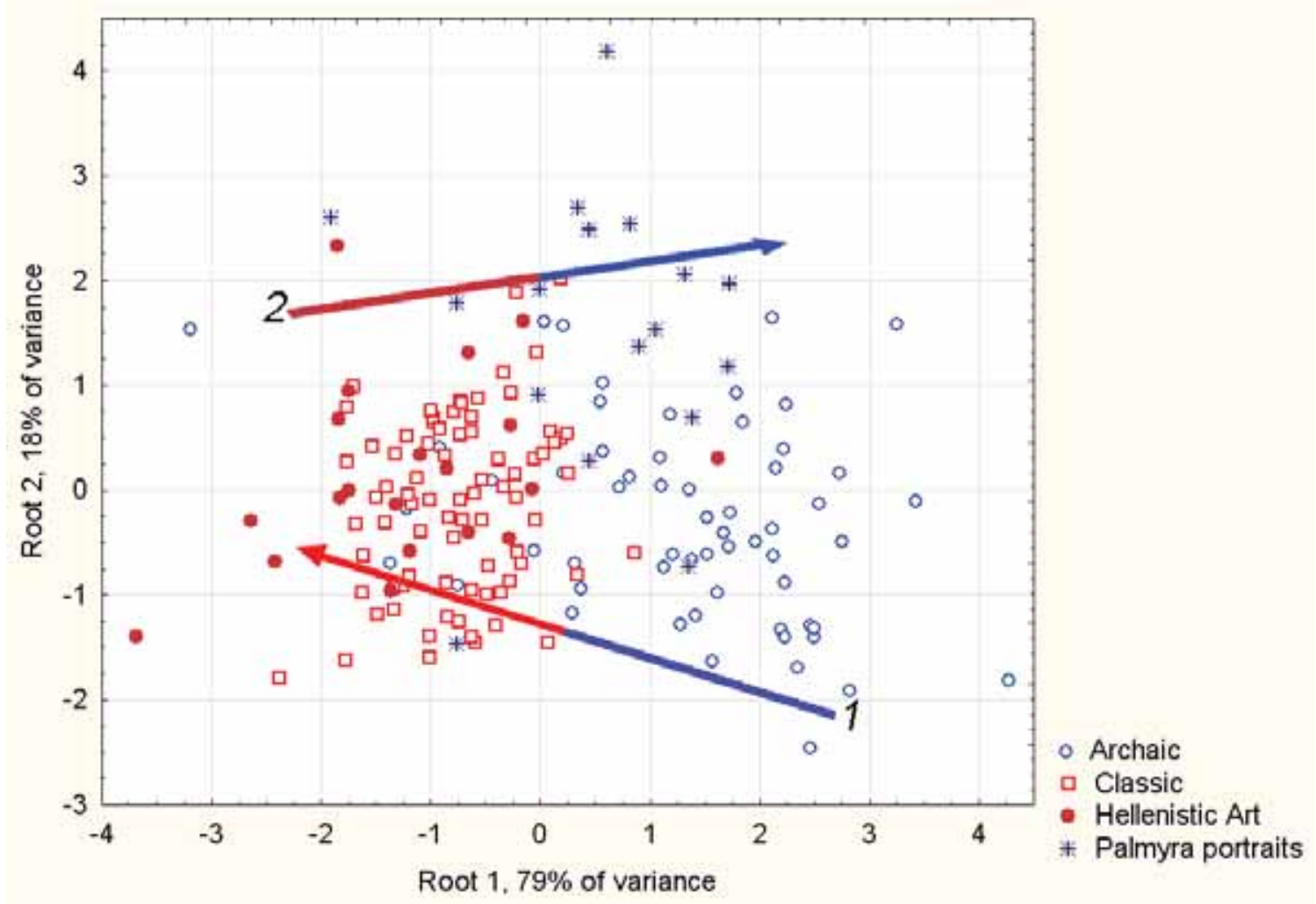

Fig. 8 The positioning of the pooled sample in the space of the first two roots.

The arrows show how systems of visual methods changed from period to period: the first arrow is from Archaic to

High Classic and Hellenistic, the second is from High Classic and Hellenistic to Palmyra funerary sculpture.

Thus, the division of the examined groups is reliable, and defined complexes of characteristics are clearly visualized. More general grouping of the material with only 4 groups (Archaic, Classic, Hellenistic and Palmyra portrait) demonstrates the same patterns. The same approaches were applied to the analysis of female sculptures. The results of division are somewhat less clear, but dividing characteristics are the same, and patterns of group differentiation remain constant regardless of the grouping principle - six or four style periods. This fact (the same patterns of intergroup variability) substantiated our deviation from the conventional anthropological principle of separate analysis of male and female samples and performance of the pooled sample analysis comprising all investigated models of sculpture.

The results of the discriminant analysis are depicted in Fig. 8. Examination of the pooled sam- ple enabled observation of the main artistic trends in creating an image of the human face in the specified historical periods. First of all, it is necessary to underline greater density of placement of the Classic sculpture in the diagram as opposed to the Archaic sculpture. At that, such compactness is observed both on the x- and y-axes. It is easy to suggest that such low variability of face proportions in the Classic sculpture is primarily explained by rigid regulations in depicting the human face, which leads to unification of the form. The second interesting fact is presence of two contradictory trends in development of the sculpture form. During the transition from the Archaic to the Classic sculpture, a shift in proportions, apart from decrease of variability can be observed: the face tends to become more triangular, with the face lower level becoming higher (especially in the Severe samples), lip thickness increases, and 


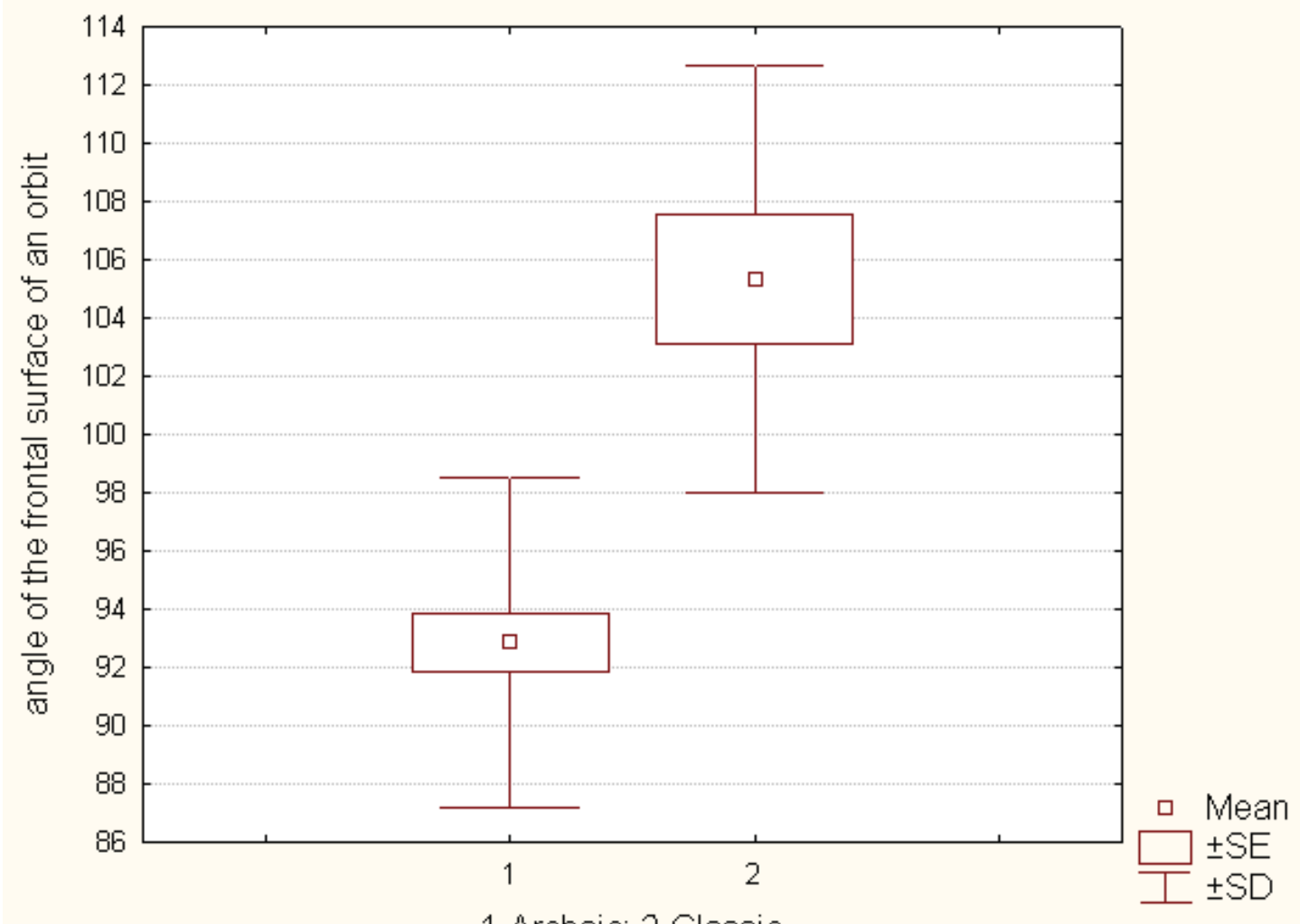

1-Archaic; 2-Classic

Fig. 9 Values of inclination angles of the orbit. Results of t-test are statistically significant. 1 - Archaic period. 2Classic period.

eyes acquire the specific "weeping" expression on account of principally different inclination of palpebral fissures. This tendency in its ultimate expression results in creation of the Hellenistic images occupying the most left positions in the field of coordinates in Fig. 8.

However, deviation from the abovementioned tendency occurs simultaneously, that is why a part of Hellenistic sculptures and, particularly, Palmyra funeral portraits return to the system of proportions characteristic for the Archaic sculpture. In other words, the face becomes more rectangular, lips thinner, and the lower level of the face decreases. As for the position of palpebral fissures, the Palmyra sample contains exemplars with both types of frontal eye placement, i.e. faces with higher outer eye corner in comparison with the inner one, but opposite variants are also presented. It should be noted that the study was particularly focused on the placement of palpebral fissures because this characteristic feature has become one of the most reliable markers in dividing different periods in the ancient sculpture. Along with that, in classifications of races the attention is also paid to the position of eyes, because the inclination of palpebral fissures is evidently connected with the degree of horizontal profile of the face: the lesser the angle of horizontal profile, especially at the orbit level, the more probable is lower placement of the outer corner of the eye in relation to the inner one.

As the eyes are particularly important features in the system of characteristics defining artistic expression of the image, we paid special attention to this area of the face. The transition from the Archaic to the Classic periods was accompanied by a shift in the relative placement of the outer and inner corner of the eye. It is not difficult to notice that Greek sculptures of different historical peri- 
ods (meaning styles) have a different structure of the cheekbone area. Archaic sculptures can be differentiated by a slightly greater convexity of the cheekbones forward, which creates the impression of a slightly flat face. Moreover, on the faces of Archaic sculptures the eyeball protrudes forward compared with the plane of the face. Ancient artists were able to convey this peculiarity perfectly depicting a slight swelling in the area of the upper eyelid. These characteristics could not escape our attention. It is established that the angle of the vertical profile of the orbit on the profile image (Fig. 4) can be reliably discriminated in sculptures of different periods (Fig. 9). The Classic sculpture has the angle of orbit inclination shifted to greater values. It means that in the Classic sculpture the cheekbone protrudes far less. The reason for faces appearing flatter is that sculptures of the Archaic period have protruding cheekbones. The correlation analysis showed presence of non-random correlations of the middle level between the vertical profile of the orbit and the degree of eyeball protrusion evaluated as a binary parameter: convexity -1 , lack of convexity - 0 (Table 1 ).

The data shows that the vertical profile of the orbit characteristic for the Archaic sculpture is connected with the presence of swelling of the upper eyelid, and, vice versa, - greater angles of the vertical profile of the orbit (Classic sculpture) correlate with its absence. It is necessary to note that the eye area structure could have been out of regulations according to the canon. In any case, extant evidences of the canon do not contain instructions on how to depict the eye area.

It enables supposition that, as opposed to face proportions, the considered characteristics of the eye area, most likely, reflect a shift of the anthropological image of the population. At that, Archaic sculptures unexpectedly recreate anthropological peculiarities typical of the Asian race: high rounded orbits (arched eyebrows) with lesser external hollows (open form of the orbit) and swelling of the upper eyelid. These features are very representative for the Archaic type, and differences between the
Classic and the Archaic types are statistically significant. Asian features in the facial structure of the ancient Greek population do not look realistic, and for this reason it is possible to suggest that these non-Greek features in the Archaic face reflect some anthropological peculiarities of a pre-Greek population of the region retained after the hellenisation of Greece and Asia Minor for a considerable period of time. These features are mentioned by some ancient writers. We would like to quote Polemon's (I-II AD) description of Ionic Greeks (according to Herodotus, Ionic Greeks, Athenians in particular originate from the Pelasgians): "...their men are rather tall with broad shoulders, handsome, wellbuilt and rather fair-skinned. Their hair is not quite fair, relatively soft and slightly wavy. Their faces are broad with high cheekbones, thin lips and straight nose. Their eyes are bright and full of fire." This ancient "verbal portrait" is in many ways a reflection of the Archaic sculpture.

\section{CONCLUSION}

Anthropological methods are able to pinpoint typological peculiarities of sculptures of different historical periods. To the great extent, these differences are manifested in the inclination of palpebral fissures, correlation of heights and widths of the face and relative thickness of lips. At the same time, the variability of face proportions in the Archaic sculpture is higher than in the Classic period, which is explained by appearance and wide distribution of the proportional canon. The revealed differences may be accounted for by the application of the proportional systems rather than by the anthropological environment.

The scope of data analysis in combination with the historical study of development of the ancient art enables determination of characteristics of the image pertaining to canonical proportions and separate features outside the canon.

The degree of convexity of the eye and the vertical profile of the orbits appears to be not included 
in the proportional characteristics of the canon because of the complexity of formalisation. Changes of these characteristics in various periods may be tentatively explained by the influence of the anthropological environment as well as peculiarities of artistic taste. These characteristics are connected both with each other and simultaneously with the period by moderate correlations.

The stability of reproduction of these characteristics on a large territory and for a considerable period of time suggests the artistic image being influenced by the existing anthropological environment of the period. The change of the image at the turn of the VI-V centuries BC probably reflects the shift in the anthropological type that took place in the distant past. For a number of reasons, this shift was actualized in art significantly later.

The obtained data analysis allows us to hypothesize existence of a pattern in the development of the artistic form not connected with the human image and not reflecting a concrete anthropological type. The study of idealized images of the human face (not connected with copying a model) demonstrates extreme closeness of Palmyra funeral images to the proportional model characteristic for Greek Archaic images. At that, proper anthropological characteristics of the image (structure of the orbital area) indicate to the number of considerable differences between the Palmyra portrait and Greek Archaic sculpture, which can probably be explained by the difference between anthropological types of Peloponnese population in IV-V centuries BC and the Roman province of Syria in the second and third centuries $\mathrm{BC}$ and to $\mathrm{AD}$. The above stated is of principal importance because the full scope of considered images, despite being attributed to different historical periods and geographical regions, is integrated by common Greco-Roman artistic tradition. The revealed tendencies and patterns represent the tendencies and patterns of cultural development of the greatest civilization regarding as the foundation of today's European artistic tradition.

\section{BIBLIOGRAPHY}

\section{Бахолдина, В. Ю. 2002}

«Закрытые» и «открытые» орбиты черепа человека. Материаль IV Международного конгресса по интегративной антропологии. Санкт-Петербург: 23-24.

Беликов А. В., Гончаров И.А. и Гончарова H. H. 2014

Алгоритмы использования оцифрованных изображений для создания обобщенного фотопортрета, Вестник Московского университета. Серия 23: Антропология, 1: 74-83.

Беликов, А. В. и Гончарова, Н. Н. 2012

Анализ изобразительного канона античной скульптуры антропологическими методами.

Вестник антропологии. Научный альманах Российской Академии наук, 22 :114-133.

\section{Герасимов, М. М. 1955}

Восстановление лица по черепу (современный u ископаемый человек).// Труды Института этнографии (новая серия), XXVIII, Москва, Академия наук СССР.

\section{Galton, F. 1879}

Combined Portraits, and the Combination of Sense Impressions Generally. Proceedings of the Birmingham Philosophical Society, 2: 26-29

\section{Perrett, D. I., May, K. and Yoshikawa S. 1994}

Facial shape and judgments of female attractiveness. Nature, 368: 239-242.

Richter, G. M. A. 1942

Kouroi: Archaic Greek Youths, Oxford University Press.

URL:http://dienekes.blogspot.ru/

date of the application to electronic resources 01.02 .2016 
REZIME

GRČKI PORTRET.

ANTROPOLOŠKA ANALIZA ANTIČKE GRČKE SKULPTURE

KLJUČNE REČI: GRČKA SKULPTURA, PROPORCIJE LICA, EVOLUCIJA UMETNIČKE SLIKE.

Članak je posvećen izučavanju mogućnosti korišćenja antropoloških metoda za identifikaciju uzoraka vajarskih dela. Autori su koristili grčku arhaičnu i klasičnu skulpturu pošto je već izučavana i može da pomogne u proučavanju nove metodologije istraživanja. Pretpostavlja se da je grčka skulptura prikaz stvarnog antropološkog tipa. Za testiranje hipoteze izmereno je više od 150 uzoraka grčke skulpture. Sa druge strane namera ovog rada je da se otkrije mehanizam evolucije grčke skulpture iz različitih vremenskih perioda. Odvajanje antropoloških karakteristika od onih koje odražavaju kulturne obrasce i trendove, kao što su kanon, izuzetno je problematično. Ipak, primena antropoloških metoda za analizu umetničkih predmeta stvara novu metodologiju i otkriva tendencije u razvoju slike. Studija nam omogućava da odvajamo karakteristike koji su povezane s kanonom od antropoloških karakteristika kao što su strukture periorbitalnog prostora i horizontalni profil lica. Stabilnost reprodukcije ovih funkcija kroz vreme i prostor ukazuju da postoji uticaj na slike iz realnog antropološkog okruženja. Promena slike u toku prelaza od arhaičnog do klasičnog doba verovatno odražava promenu antropološkog tipa koji se dogodio u dalekoj prošlosti. 